\title{
Sustainable Pedagogical Leadership in Finnish Early Childhood Education (ECE): An Evaluation by ECE Professionals
}

\author{
Elina Fonsén ${ }^{1}\left(\mathbb{D} \cdot\right.$ Ulla Soukainen $^{2}$
}

Published online: 18 October 2019

(c) The Author(s) 2019

\begin{abstract}
According to previous research, the leadership in early childhood education (ECE) needs to be strengthened and improved by building sustainable structures. The aim of the current research was to investigate how ECE professionals evaluate its leadership. The context of the study was a development project called Sustainable leadership in ECE conducted in two municipalities in Finland. The purpose of the project was to investigate and create a sustainable structure for ECE leadership with the aim of strengthening pedagogical leadership. The participants were 110 ECE professionals, comprising experts, directors, teachers, and nurses. The research was based on responses to an electronic questionnaire about the quality of ECE leadership built around six themes: leadership of the organisation, Human resource management, Structure of the organisation, Pedagogical leadership, Knowledge management and work well-being, and Leadership of self. The results indicate that only in the pedagogical leadership theme were there statistically significant differences between the groups of professionals. Having high professional status and being highly qualified seem to enhance the ability of professionals to reflect critically on pedagogical leadership and to have more demanding attitudes about the quality of pedagogical leadership.
\end{abstract}

Keywords Early childhood education $\cdot$ Sustainable leadership $\cdot$ Pedagogical leadership $\cdot$ Assessment of leadership

\section{Introduction}

Pedagogical leadership is considered to be an important aspect of leading an educational organisation (Sergiovanni 1998). However, it is an indefinable phenomenon and its implementation is even more confusing. Recent rapid changes in Finnish early childhood education (ECE), the demands of new legislation and the lack of qualified personnel has been confusing for the directors. For these reasons, more research into ECE leadership is needed to form theories (see Gotvassli 2018; Ødegård 2011). Researchers (e.g. Fonsén 2014; Sergiovanni 1998) have tried to define pedagogical leadership as a concept and provide the methods appropriate for its practical application. However, the

Elina Fonsén

elina.fonsen@helsinki.fi

Ulla Soukainen

ulla.soukainen@avi.fi

1 Faculty of Educational Sciences, University of Helsinki, Siltavuorenpenger 10, PL 8, 00014 Helsinki, Finland

2 Regional State Administrative Agency for Southwestern Finland, P.O. Box 22, 20801 Turku, Finland professionals in the field of ECE are not well apprised of these. The crucial factor seems to be to construct a shared understanding of the pedagogical leadership of the organisation (Keski-Rauska et al. 2016). Helin et al. (2018) pointed out that leadership discourses have a central impact when building a shared understanding inside organisations. In addition, dialogue and a mutual understanding about pedagogy has a major impact on the quality of that pedagogy. Consequently, dialogue about pedagogy and participation in development means that pedagogical leadership is a form of distributed leadership. Shared leadership is therefore a shared awareness, responsibility and action that is consciously planned, directed and coordinated by a person in a leadership position (Heikka 2014).

In this study, we have investigated the views expressed by the different groups of ECE professionals about pedagogical leadership. The methods used in this research were a quantitative survey questionnaire and statistical test using SPSS software, after which interviews were held and subjected to discourse analysis to identify discourses from the stakeholders' explanations about the assessment of the results. However, the focus in this study is the quantitative analysis 
of survey data. The discourse analyses have been reported in another article (Fonsén and Keski-Rauska 2018).

The context of the research was a development project entitled "Sustainable leadership in early childhood education" carried out in two municipalities in Finland. The focus of the development project was to design a good model for pedagogical leadership. Sustainable leadership is based on trust and distributed leadership and it commits the staff to being responsible actors. The distributed leadership perspective emphasizes the process of learning together and constructing meaning and knowledge collectively and collaboratively (Hargreaves and Fink 2006). According to Sergiovanni (1998), pedagogical leadership invests in capacity building by developing social and academic capital for students, and intellectual and professional capital for teachers. Although teachers share the responsibility for pedagogical leadership with the leaders, it is the main duty of the leaders (Fonsén 2013, 2014; Soukainen 2015). The concept of sustainable leadership in ECE is based on Hargreaves' seven principles of sustainable leadership (Hargreaves 2006). By studying Hargreaves' principles in this development project, our aim was to construct a sustainable pedagogical leadership model for ECE.

\section{Finnish ECE in Changing Policy Environment}

Finnish ECE has been subjected to many changes at the national level in recent years. The administration of ECE was transferred from the Ministry of Social Affairs and Health to the Ministry of Education and Culture in 2013. Both the law and the National Core Curriculum have been updated of late. The first "loop" of reform of the Act on Early Childhood Education and Care took place in 2015 and the curriculum change followed in autumn 2016 and again in 2018 (Act on Early Childhood Education and Care 540/2018; National Core Curriculum on Early Childhood Education and Care 2018). The second phase of the revised Act on Early Childhood Education and Care (540/2018) came into force on 1 September 2018. The new law and the new national curriculum are a challenge for pedagogical leadership due to the higher pedagogical demands imposed on ECE.

Despite the national renewal, the economic challenges in the field of ECE for the municipalities have led to pressures to reduce costs. Consequently, the responsibility areas of directors have been expanded. Furthermore, multiple changes in organisations can disrupt employees' minds and affect their opinions about work well-being. The insecurity may also influence pedagogical quality. These changes can be both macro-level national and institutional changes and micro-level occupational or staff structure changes. As Hujala (2019) has stated, "The demand for increasing research-based knowledge on EC leadership is huge as being experienced by leadership actors and specialists on the ECE field including the academic and professional organizations" (p. 9). Vlasov (2018) argues that another challenge for ECE is the changed role of parents as clients. Eventually these changes and the increased complexity of society have meant that the leadership also had to change.

Consequently, the need to strengthen pedagogical leadership and to find new forms of it have been topical (see Fonsén and Vlasov 2017). Leadership structures are being reviewed in many municipalities and it has led to the need to find a sustainable leadership model for ECE. (See also Soukainen 2018; Soukainen and Fonsén 2018).

\section{Sustainable Pedagogical Leadership in ECE}

In this study, ECE leadership is seen through two theoretical lenses: the authors' pedagogical leadership in which the pedagogical core task of ECE determines the leadership in ECE (Fonsén 2013, 2014) and Hargreaves and Fink's (2006) idea of sustainable leadership. According to Hargreaves (2007), sustainable leadership creates and preserves sustainable learning, secures success over time, sustains the leadership of others, addresses issues of social justice, develops rather than depletes human and material resources, develops environmental diversity and capacity, and undertakes activist engagement with the environment. According to the theory of pedagogical leadership, leadership needs to be built on the main task of the organisation. Furthermore, as shown in Fig. 1, the main power cog of pedagogical leadership contains values, reflective discussion and development work towards the vision (Fonsén 2014). It requires all stakeholders to have enough knowledge about the quality of pedagogy. We need pedagogically-qualified leaders and teachers who can share the vision of high-quality pedagogy in ECE. In addition, ECE leaders need to have management skills to guide the teachers in working with high-quality pedagogy. Furthermore, the skill to lead the curriculum work is needed.

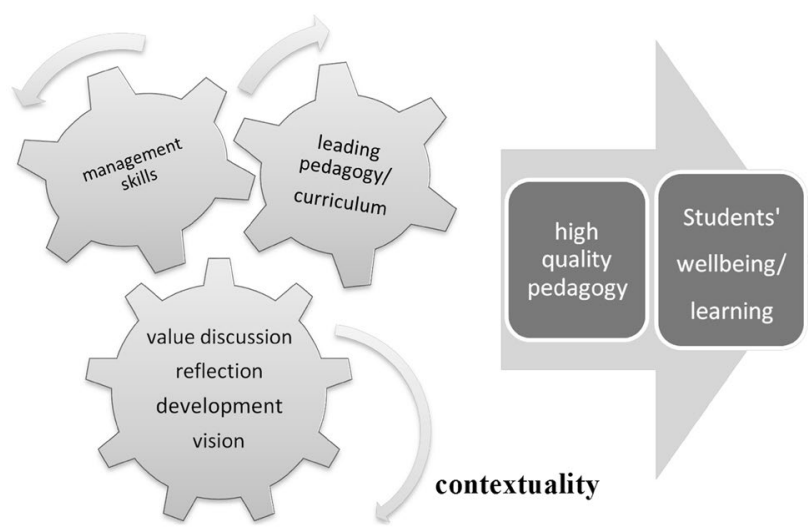

Fig. 1 Power of pedagogical leadership (Fonsén 2014) 
Fonsén (2013) argues that context is the one of the determinants of leadership. The structure of the organisation can either prevent or promote pedagogical leadership. Sustainable pedagogical leadership in ECE means that a common understanding about the key factors influencing the leadership structure is needed. Shared values and vision were mentioned above. In addition, sustainability in leadership highlights the importance of strategy, communication, development work and pedagogical leadership structure.

Halttunen (2009) has pointed out that in the Finnish ECE leadership context, fragmented leadership has dominated since the 1990s. A single director leads more distributed organisations, many separate units and different models of early childhood education (e.g., childcare centres, family day care and clubs), which alienates the director from the everyday work in ECE. Therefore, the number of administrative tasks increases and time to focus on pedagogical leadership decreases. It challenges the redefinition of leadership and the search for sustainable leadership. Distributed leadership needs mutual understanding and discussion in an organisation, and through this, staff members will become aware of what is expected of them.

According to Soukainen (2015), leadership in a distributed organisation requires both the director and the personnel to be aware that they work in a distributed organisation. Directors must lead themselves so that they can also lead their employees and the task images must be clearly defined. Leadership development includes self-evaluation and the changing roles of the leader required by the situation in which the directors find themselves. Soukainen (2015) argues that leadership in ECE is complicated because many elements emerge at the same time. These elements include context, the employees, stakeholders' demands and the requirements of the families. It is therefore impossible to give an unambiguous answer about how to act in different situations.

Crossan et al. (2008) outlined the three levels of strategic leadership that leaders need to manage: leadership of self, leadership of others, and leadership of organisation. Akselin (2013) used this model in her dissertation about strategic leadership in ECE and found that few ECE directors are able to manage all three levels. Also, Halttunen (2015) has pointed out the lack of training for current leaders. There have been many discussions regarding the professional qualifications of ECE leaders in Finland and the new minimum qualification requirement is to become a master's degree in education by 2023 (Act on Early Childhood Education and Care, 540/2018).

In addition to the qualified leaders, the functionality of an organisation's structure is important for pedagogical leadership (Fonsén 2013, 2014; Hujala 2004). As Soukainen (2015) has argued, the two key issues in leading ECE are its structure and substance. The contextual leadership model
(Hujala 2004) sees leadership as the responsibility of all leadership levels in ECE organisations. The macro level consists of the governance and administration of ECE and at the micro level, it consists of the centre's personnel: directors, teachers and nurses. Heikka (2014) argues that macro-level stakeholders' perspectives differ from micro-level stakeholders' perspectives. They did not have discussion arenas and a shared understanding about the pedagogy or pedagogical leadership structure.

The discursive element in organisations underlines how leadership is experienced. Fonsén and Keski-Rauska (2018) found both negative and positive discourses while researching leadership and work wellbeing in the different units for which the same leadership pair were responsible. First, in quantitative research, the differences between half of the units in the research had a statistically significant difference in their assessments of the leadership. In further qualitative discourse analysis, the satisfaction or dissatisfaction with leadership was seen to be related to seeing leadership as part of an organisational culture in a holistic way (Fonsén and Keski-Rauska 2018).

Hargreaves and Fink (2006) argue that sustainable leadership is distributed leadership, but in a certain way. Distribution should be done by sharing the ideas, values and the purpose of the work. If leaders are too autocratic, there is a risk that distributed leadership will be only delegating the tasks to staff. Another risk is that a leader could neglect leadership, leading to anarchy due to nobody taking responsibility.

"Change in education is easy to propose, hard to implement, and extraordinarily difficult to sustain" argue Hargreaves and Fink (2006, p. 6). Bøe and Hognestad (2019) state that sustainable improvements in educational settings depend on successful leadership.

Viewing leadership in an ECE context shows that leadership is embedded in the pedagogical leaders' practices. Those responsible for pedagogical leadership must direct staff to enhance children's learning. "They use their professional knowledge as early childhood teachers as a base on which they adapt to the situation" (Bøe and Hognestad 2019, pp. 268-269).

According to Hargreaves and Shirley (2009) sustainable leadership is a democratic and professional way to build improvement from the bottom up and it will cause changes in direction from the top. In addition, support is provided from both directions. It builds powerful, responsible, and lively professional communities by empowering teachers. It is a shared responsibility and it will enhance human resources. Hargreaves and Fink (2003) described the cross-fertilization of good ideas and successful practices as the basis of shared learning and development in sustainable leadership.

Finnish school achievements are based on guidingnot controlling-governance, Hargreaves and Shirley (2009) have stated. It has resulted in the trust in teaching 
professionalism being strong. Behind this lie the six pillars of purpose and partnership, according to Hargreaves and Shirley (2009), which are built on an inspiring and inclusive vision, a strong public engagement, achievement through investment, corporate educational responsibility, and students as partners in change and mindful learning and teaching. Kocolowski (2010) also claims that while leadership is distributed, it promotes the commitment of all parties to a common goal.

Hargreaves and Fink (2006) argue that sustainable leadership lasts by emphasizing the more valuable aspects of learning. Within their definition, the process is ongoing over time, year after year, and from one leader to the next. One of the more important things is to secure teachers' ownership of the changes. Without their inclusion, continual changes may lead many teachers to burning out. Alongside having changes, organisations also need to be able to forget, an action described as "degradation" by Hargreaves and Fink (2006). They have listed certain cases when forgetting is necessary. The first one is if the curriculum is outdated. In Finnish ECE, the revised curriculum and the new legislation are current issues. These cause instability in the field due to the changing demands of pedagogy. Hargreaves and Fink (2006) continue by mentioning the inoperative pedagogies and professionalism that have no regard for evidence or research. There is considerable new research which has provided convincing evidence for requiring a critical reflection of the pedagogy implemented. In their conclusion, Hargreaves and Fink (2006) mention that there are tasks in teaching and management that can be handled by someone else. It is important to distinguish those tasks from the tasks that leaders and teachers should focus on. Finnish ECE organisations have changed during the last 10 years and the question of the responsibilities and tasks of the different groups of professionals has become a topical issue. The new Act on Early Childhood Education and Care (540/2018) also imposes demands on future tasks due to new professional titles and qualifications.

\section{The Context of the Study}

The "Sustainable leadership in ECE" development project started in early 2015 and ended in August 2016. A private educational research company (Ediva oy) was the implementer of the project and the research was conducted in the School of Education at the University of Tampere. The project's other stakeholders were two municipalities in Finland. The aim of the project was to develop a sustainable model for leadership in ECE at the municipal and centre levels.

The 110 participants were directors (also from the administration), deputy directors, experts, special education teachers, teachers, and nurses. In this study, they have been categorized into the following professional groups: Directors (directors and deputy directors of childcare centres, directors from the administration), Teachers, Nurses, and Experts (special education teachers, service chiefs). Deputy Directors usually work in groups as teachers and they act as directors when the director is absent. Teachers have responsibility for the pedagogy of early childhood education. They have been awarded a bachelor's degree from a university or university of applied sciences (polytechnic). Special education teachers work with children with special needs. They can work in child groups or as consultative special education teachers. Service chiefs are planners or developers, or they have responsibility for special areas (such as computer applications). Nurses are trained in vocational institutions and they have undertaken less pedagogical study than teachers have, or have not studied pedagogy at all.

The first part of the project was to reflect on the style of leadership that is implemented and make the changes for leadership in the autumn of 2015. The next step was bringing innovations into practice through pilot phases during winter 2015 and spring 2016. The evaluation and consolidation of renewed leadership took part in spring and summer 2016 and the evaluation and dissemination of the results was done in autumn and winter 2016.

\section{Research Questions}

The purpose of the study was to investigate the assessments of different groups of professionals concerning ECE leadership and the differences between these professionals' assessments. The research questions were:

How do ECE professionals evaluate the ECE leadership?

Are there differences in the assessments of ECE leadership between the groups of professionals?

What are the differences in the assessments of ECE leadership between the groups of professionals?

\section{Conducting the Study}

The data were collected through an electronical survey with a questionnaire on the quality of ECE leadership. The questionnaire was designed for this study and the themes were built according to theoretical knowledge based on the research of Crossan et al. (2008), particularly their model of three levels of strategic leadership and the Fonséns' (2014) model of 'the power of pedagogical leadership'. The questionnaire is attached as "Appendix 1". The questionnaire comprised 30 items, which model six themes:

(1) Leadership of the organisation

(2) Human resource management 
(3) Structure of the organisation

(4) Pedagogical leadership

(5) Knowledge management and work well-being and

(6) Leadership of self.

Items on the Leadership of organisation theme (1) included questions about the strategy, values, mission, and development of organisation at the ECE municipal and unit levels. The human resource management theme (2) was concerned with questions about the ability of the leadership teams to motivate and hear the employees, support their professional development, and draw up clear job descriptions. In the Structure of organisation theme (3), the question asked was if the structure of an organisation is functional across several aspects, which are distributed management levels, management responsibilities, and communication and information.

The pedagogical leadership theme (4) sought to evaluate items relating to the execution of ECE planning and the structure of pedagogical leadership. There is also a question about the developing of pedagogy based on assessment. The aim of the theme of Knowledge management and work well-being (5) was to evaluate if the employees' knowledge is utilised in pedagogical activity and in the development of pedagogical activity. There are also questions about atmosphere and developing work wellbeing. The Leadership of self (6) theme asks if leaders intend to improve themselves and their readiness to change their approaches and take on new tasks and challenges.

The survey was carried out to find out which structures and dimensions needed to be improved in leadership issues in 2015 during the "Sustainable leadership in ECE" development project. Participants in the project and this study were 110 ECE directors and staff members from two municipalities in Finland. Sixty-two of the participants came from a larger municipality and 48 from a smaller municipality. The assessments were made according to a Likert-type scale from 1 to 5 , where value 1 describes low quality and value 5 describes high quality.

The reliability of the themes was investigated using SPSS software. The internal consistency of the dimensions was computed using Cronbach's alphas. The reliability of the dimensions tested by Cronbach's Alphas was the following: Theme $1=0.891$, theme $2=0.859$, theme $3=0.872$, theme $4=0.860$, theme $5=0.864$. The reliability proved to be good when a reliability coefficient of 0.70 or higher is considered acceptable (Heikkilä 2008). Only in theme $6=0.668$ did reliability prove to be slightly under the 0.70 limit.

Additional data were collected according to assessment results. The complementary interviews were conducted to explain the reasons behind the results. However, the focus of this article is on the results of the quantitative data; the results from the interviews were analysed discursively and reported by Soukainen and Fonsén (2018).

\section{Results}

The results of the assessment were examined by dividing the answers into the different ECE professional groups. The groups were experts, directors, teachers, and nurses. The experts are the heads of the civil service and special early childhood education teachers. The directors are ECE centre directors with ECE teaching qualifications and they may have additional management training; the teachers are ECE teachers who have completed at least a bachelor's degree, or upper vocational studies at a university of applied sciences; and nurses have vocational training (Table 1).

The normal distributions of the factors were tested with the Shapiro-Wilk test before analysing the data. The test (the Shapiro-Wilk test result was lower than 0.05) indicated that the distributions of the factors were skewed in factors (3) Structure of organisation, (4) Pedagogical leadership,

Table 1 The assessments of leadership themes by different ECE professionals

\begin{tabular}{|c|c|c|c|c|c|c|c|c|c|}
\hline \multirow[t]{2}{*}{ Theme } & \multicolumn{2}{|c|}{ Directors } & \multicolumn{2}{|c|}{ Teachers } & \multicolumn{2}{|c|}{ Nurses } & \multicolumn{2}{|c|}{ Experts } & \multirow{2}{*}{$\begin{array}{l}\text { Kruskall-Wallis } \\
\text { test (One Way } \\
\text { anova) } \\
p\end{array}$} \\
\hline & Mean & $\mathrm{SD}$ & Mean & $\mathrm{SD}$ & Mean & SD & Mean & SD & \\
\hline Leadership of organisation & 4.00 & 0.337 & 3.74 & 0.658 & 3.90 & 0.619 & 3.57 & 0.485 & $\begin{array}{l}.127 \\
(.187)\end{array}$ \\
\hline Human resource management & 3.94 & 0.478 & 3.88 & 0.838 & 4.04 & 0.678 & 3.61 & 0.705 & $\begin{array}{l}.273 \\
(.307)\end{array}$ \\
\hline Structure of organisation & 4.00 & 0.620 & 3.88 & 0.822 & 3.83 & 0.688 & 3.50 & 0.610 & .175 \\
\hline Pedagogical leadership & 3.87 & 0.725 & 4.02 & 0.719 & 4.20 & 0.494 & 3.37 & 0.622 & $.002 * *$ \\
\hline $\begin{array}{l}\text { Knowledge management and } \\
\text { work wellbeing }\end{array}$ & 3.97 & 0.476 & 3.99 & 0.737 & 4.01 & 0.528 & 3.83 & 0.515 & $\begin{array}{l}.478 \\
(.822)\end{array}$ \\
\hline Leadership of self & 4.31 & 0.441 & 4.41 & 0.383 & 4.25 & 0.618 & 4.34 & 0.400 & .780 \\
\hline$n$ & 12 & & 40 & & 37 & & 14 & & \\
\hline
\end{tabular}

$* * * p<.001, * * p<.01, * p<.05$ 
and (6) Leadership of self. Therefore, the statistical significance was tested between the sum score of the assessments of the respondent groups with the non-parametric test. The Kruskal-Wallis test was chosen to assess for significant differences between the categorical independent variables when there are more than two groups.

In factors (1) Leadership of Organisation, (2) Human resource management, and (5) Knowledge management and work wellbeing, the distributions of the sum scores were partly normally distributed (the Shapiro-Wilk test result was higher than 0.05). In addition, a one-way ANOVA test was done. The results confirmed that there was no statistical significant difference between the sum scores of assessments by these tested groups.

The difference between the groups tested was statistically significant only in the pedagogical leadership theme. As can be seen in Fig. 2, the higher the level of the pedagogical professionals, the lower is their assessment of pedagogical leadership. The nursery nurses have the lowest level of pedagogical qualification and their assessment was the highest (4.20), followed by the teachers' evaluation (4.02), and that of the directors (3.87). The experts who are supposed to be the best pedagogy specialists gave the lowest assessments (3.37) for pedagogical leadership.

A closer inspection was conducted on the items relating to pedagogical leadership (see "Appendix 2", Table 2). Statistical differences were recorded for all items except for item 20) Pedagogy is developed through assessment. The same phenomenon can be recognised in the inspection of individual items than in the theme of pedagogical leadership. The professionals with higher levels of pedagogical education gave the lowest assessments (Fig. 3).

Item (18) The early childhood education curriculum is a guiding document in practice, was accorded a very high evaluation from nurses (4.51) and it was very highly evaluated by the other professionals except for the teachers, who evaluated it lower than item (19) The individual early childhood education plans for children define and instruct the

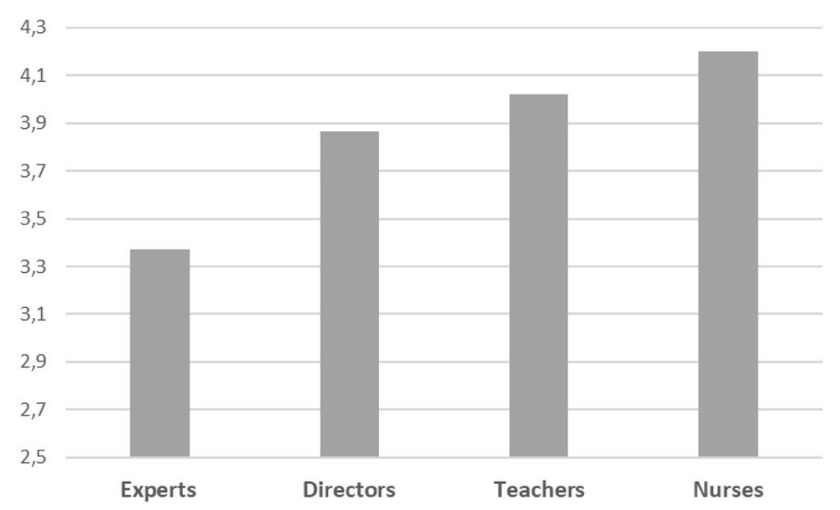

Fig. 2 The assessments of pedagogical leadership made by professionals in ECE pedagogical activities of the group. In addition, item 18 was the only item for which the teachers recorded a lower evaluation than the directors' evaluation. It seems that teachers appreciate the children's individual education plans more than the ECE curriculum as a source of guidance for the pedagogy implemented for the child groups.

The low results for items (16) The units have a design for and construction of the pedagogical leadership, and (17) Pedagogical leadership is realized according to the planned structure, show that the need to improve pedagogical leadership and structure for pedagogical leadership is crucial.

\section{Study Limitations}

A possible limitation resulted from the data being collected from the stakeholders of a developing project. The results may not be generalised across all ECE professionals because of the positive attitude to the development project that participants already have. The Quality of ECE leadership questionnaire gives an overall view about leadership issues but more detailed or deeper information would need to be gathered through additional interviews.

\section{Discussion and Conclusions}

The results of the study confirm that the participants lack consensus in their views about pedagogical leadership, and state the current need to strengthen the structure of pedagogical leadership in ECE through common discussions with all professionals.

The most interesting result was that a lower professional qualification was correlated with a higher evaluation of pedagogical leadership issues and vice versa. The higher educational background and professional position of informants was in connection with the lower evaluation result for pedagogical leadership. ECE directors and experts evaluated the pedagogical leadership structures more critically than the teachers and nurses who work at the ECE centres.

The need to strengthen pedagogical leadership is required due to changes in society and new demands being imposed on ECE (see Vlasov 2018). Those professionals who look at the organisations from a distance may see the "whole picture" better. They can be more critical of pedagogical leadership due to their understanding of the development needs of the leadership structure and the crucial need to develop the pedagogy. Directors and experts are also more aware of the economic and structural challenges of the organisation. The number of the directors' work tasks and duties are not very clear to teachers and nurses. Instead of that wider perspective, the teachers and nurses are working close to children 
Fig. 3 The assessments of pedagogical leadership items made by different professionals in $\mathrm{ECE}$

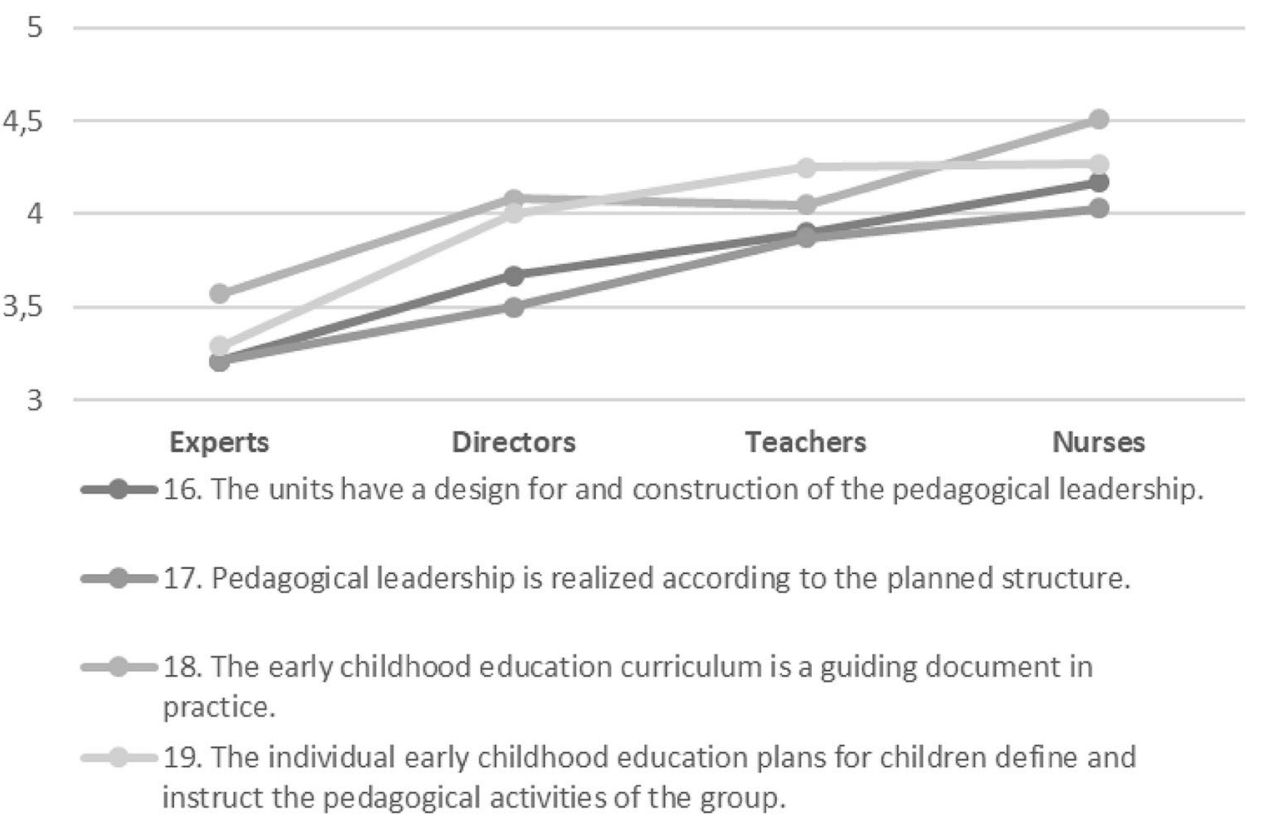

and they see the demands for pedagogy that arise from the children's needs and interests. The way the teachers see the role of curriculum differs from the directors' opinions. While directors preferred the curriculum to be a guiding document of pedagogical practices, the teachers saw the role of the children's individual plans as being more crucial for implemented pedagogical practices. They operate more with children's individual ECE plans and the curriculum provides background information for their daily work. Teachers and nurses are uncritical of the overall pedagogical leadership structure because they may not see the impact of the leadership structures so clearly in their everyday work. As Urban and Dalli (2012) have stated, early childhood educators mostly see their professional work in the immediate context in their contact with children.

While the ECE teachers' view of their pedagogical work was examined by Ukkonen-Mikkola and Fonsén (2018) using Layder's research map, the context-level issues were rarely mentioned. The stronger attention (according to Layder's definition) achieved situated actions and level-setting issues. However, the level-setting dimension in the study mentioned includes pedagogical leadership as an example of the structure of pedagogical discussion at ECE centres (Ukkonen-Mikkola and Fonsén 2018). It can be concluded that pedagogical leadership structures are important for ECE teachers but directors and experts in ECE see the developmental needs as being more important. As Fonsén (2014) argues, the importance of critical reflection is one of the tools when the power of pedagogical leadership is discussed. However, according to Hargreaves and Fink (2006), it is essential to secure teachers' ownership of the changes. If the changes are made "top down", there is a serious risk of teachers becoming exhausted. Semann (2019) claims "effective pedagogical leadership is a collective journey, which includes all staff working together to identify the strategic direction they hope to work towards" (p. 55).

The pedagogical core task of ECE should be to determine the leadership in ECE as well as considering the teachers' pedagogical work (see Fonsén 2014; Soukainen 2015). In addition, the leadership discourse is crucial, while the shared understanding is formed from the shared pedagogical vision. A mutual understanding of the development of pedagogical leadership structures is needed (Heikka 2014; Fonsén and Mäntyjärvi 2019). Likewise, Hargreaves and Shirley (2009) state that an inspiring and inclusive vision is one of the six pillars of purpose and partnership in sustainable leadership. It means that more discussion is needed about pedagogical leadership issues, as the results of this study have pointed out. The mutual understanding about the success of the leadership is crucial.

Besides "the leadership of others and the leadership of organisation", leaders need to manage "the leadership of self" (Crossan et al. 2008). It is important for directors to lead themselves, but it is also important for teachers and nurses. By reflecting on one's own work, it is possible to improve knowledge and expertise. As Corrick and Reed (2019) argue: "Pedagogical leadership is an opportunity to rethink and consider ways of encouraging people in a staff team to demonstrate the ability to be self-directed" (p. 69).

As a conclusion of this research, seeing pedagogy from different perspectives enhances mutual understanding, which requires time for discussion. The structure of ECE leadership needs further clarification because the places for discussions must be established. Therefore, other development projects-such as those described in this 
article- - are needed to develop mutual understanding and sustainable pedagogical leadership structures.

Acknowledgments Open access funding provided by University of Helsinki including Helsinki University Central Hospital.

\section{Compliance with Ethical Standards}

Conflict of interest The authors declare that they have no conflict of interest.

Informed Consent Informed consent was obtained from all individual participants included in the study.

Open Access This article is distributed under the terms of the Creative Commons Attribution 4.0 International License (http://creativeco mmons.org/licenses/by/4.0/), which permits unrestricted use, distribution, and reproduction in any medium, provided you give appropriate credit to the original author(s) and the source, provide a link to the Creative Commons license, and indicate if changes were made.

\section{Appendix 1}

\section{The Questionnaire of the Quality of ECE Leadership Survey}

\section{Theme 1: Leadership of Organisation}

1. The municipal ECE leadership team has a clear, shared vision.

2. The ECE unit has a clear, shared vision.

3. The municipal ECE leadership team's work is based on common defined values.

4. The ECE unit's activities are based on common defined values.

5. The municipal ECE leadership team has a functional strategy.

6. The municipal ECE leadership team utilises the information received from the employees in planning and developing the pedagogy.

7. The information gathered from stakeholders and from employees is taken into account in the strategy of the organisation.

8. The municipal ECE leadership team regularly communicates about the strategy and the need for change.

\section{Theme 2: Human Resource Management}

9. The employees rely on the municipal ECE leadership team's ability to utilise the initiatives they have submitted.

10. The employees are motivated to develop their work.

11. Job descriptions are clear and known to all.
12. The municipal ECE leadership team supports the pedagogical development.

\section{Theme 3: Structure of Organisation}

13. The structure of organisation is functional: Management levels (directors, managers, vice-directors, teachers of special needs, personnel)

14. The structure of organisation is functional: Management responsibilities

15. The structure of organisation is functional: Communication and information

\section{Theme 4: Pedagogical Leadership}

16. The units have a design for and construction of the pedagogical leadership.

17. Pedagogical leadership is realized according to the planned structure.

18. The early childhood education curriculum is a guiding document in practice.

19. The individual early childhood education plans for children define and instruct the pedagogical activities of the group.

20. Pedagogy is developed through assessment.

\section{Theme 5: Knowledge Management and Work Wellbeing}

21. Employees' knowledge is utilised in pedagogical activity.

22. Employees' knowledge is utilised in the development of pedagogical activity.

23. Employees' knowledge is developed systematically.

24. The atmosphere in the working community is good.

25. Wellbeing at work is being developed systematically.

26. The working community culture is open and supportive.

\section{Theme 6: Leadership of Self}

27. I have enough knowledge for my present work.

28. I want to develop myself and my skills.

29. I am ready to take on new tasks and challenges.

30. I have readiness, if necessary, to change my approach.

\section{Appendix 2}

See Table 2. 
Table 2 Assessments of pedagogical leadership by ECE professionals

\begin{tabular}{|c|c|c|c|c|c|c|c|c|c|}
\hline \multirow{2}{*}{$\begin{array}{l}\text { Pedagogical leadership } \\
\text { Item }\end{array}$} & \multicolumn{2}{|c|}{ Directors } & \multicolumn{2}{|c|}{ Teachers } & \multicolumn{2}{|l|}{ Nurses } & \multicolumn{2}{|c|}{ Experts } & \multirow{2}{*}{$\begin{array}{l}\text { Kruskal- } \\
\text { Wallis } \\
\text { test } \\
p\end{array}$} \\
\hline & Mean & SD & Mean & $\mathrm{SD}$ & $\overline{\text { Mean }}$ & SD & $\overline{\text { Mean }}$ & SD & \\
\hline $\begin{array}{l}\text { 16. The units have a design for and construction of the pedagogical } \\
\text { leadership }\end{array}$ & 3.67 & 0.778 & 3.9 & 0.871 & 4.17 & 0.655 & 3.21 & 0.893 & $\begin{array}{l}.004 \\
* *\end{array}$ \\
\hline 17. Pedagogical leadership is realised according to the planned structure & 3.50 & 0.905 & 3.87 & 0.822 & 4.03 & 0.654 & 3.21 & 0.893 & $\begin{array}{l}.005 \\
* *\end{array}$ \\
\hline $\begin{array}{l}\text { 18. The early childhood education curriculum is a guiding document in } \\
\text { practice }\end{array}$ & 4.08 & 0.793 & 4.05 & 0.876 & 4.51 & 0.559 & 3.57 & 0.938 & $\begin{array}{l}.002 \\
* *\end{array}$ \\
\hline $\begin{array}{l}\text { 19. The individual early childhood education plans for children define } \\
\text { and instruct the pedagogical activities of the group }\end{array}$ & 4.00 & 0.953 & 4.25 & 0.63 & 4.27 & 0.732 & 3.29 & 0.726 & $\begin{array}{l}.001 \\
* *\end{array}$ \\
\hline 20. Pedagogy is developed through assessment & 4.08 & 0.793 & 4.03 & 0.92 & 4.05 & 0.78 & 3.57 & 1.016 & .261 \\
\hline$n$ & 12 & & 40 & & 37 & & 14 & & \\
\hline
\end{tabular}

$* * * p<.001, * * p<.01, * p<.05$

\section{References}

Act on Early Childhood Education and Care. (540/2018). Ministry of Education and Culture. Finland.

Akselin, M.-L. (2013). Varhaiskasvatuksen strategisen johtamisen rakentuminen ja menestymisen ennakoiminen johtamistyön tarinoiden valossa. Akateeminen väitöskirja. Tampereen yliopisto. Kasvatustieteiden yksikkö. Acta Electronica Universitatis Tamperensis: 1283. Retrieved December 11, 2018 from http://tampu b.uta.fi/handle/10024/67985

Bøe, M., \& Hognestad, K. (2019). The dynamics of pedagogical leaders' everyday leadership. In P. T. Granrusten, K.-A. Gotvassli, O. F. Lillemyr, \& K. H. Moen (Eds.), Leadership for learning: The new challenge in early childhood education and care (pp. 259-272). Charlotte: Information Age Publishing.

Corrick, G., \& Reed, M. (2019). Pedagogical leadership. Challenges and opportunities. In S. Cheeseman \& R. Walker (Eds.), Pedagogies for leading practice (pp. 65-77). London: Routledge.

Crossan, M., Vera, D., \& Nanjad, L. (2008). Transcendent leadership: Strategic leadership in dynamic environments. The Leadership Quarterly, 19, 569-581.

Fonsén, E. (2013). Dimensions of pedagogical leadership in early childhood education and care. In E. Hujala, M. Waniganayake \& J. Rodd (Eds.), Researching leadership in early childhood education (pp. 181-192). Tampere: Tampere University Press

Fonsén, E. (2014). Pedagoginen johtajuus varhaiskasvatuksessa.[Pedagogical leadership in Early Childhood Education] Acta Universitatis Tamperensis 1914. Tampere: Tampere University Press. Retrieved November 28, 2018 from http://tampub.uta.fi/bitstream/ handle/10024/95050/978-951-44-9397-3.pdf?sequence=1.

Fonsén, E., \& Keski-Rauska, M.-L. (2018). Varhaiskasvatuksen yhteinen johtajuus vastakohtaisten diskurssien valossa. Työelämän tutkimus, 16(3), 185-200.

Fonsén, E. \& Mäntyjärvi, M. (2019). Diversity of the assessments of a joint leadership model in early childhood education. In P. Strehmel, J. Heikka, E. Hujala, J. Rodd \& M. Waniganayake (Eds.), Leadership in early education in times of change. Research from five continents (pp. 154-169). Opladen: Verlag Barbara Budrich.

Fonsén, E. \& Vlasov, J. (2017). Leading pedagogical quality in the context of Finnish child care. In C. Ringsmose \& G. KraghMüller (Eds.), The nordic social pedagogical approach to early years. Series: International perspectives on early childhood education and development (Vol. 15, pp. 253-265). Cham: Springer International Publishing AG.

Gotvassli, K. (2018). Leadership in early childhood centers. In P. T. Granrusten, K. Gotvassli, O. F. Lillemyr, \& K. H. Moen (Eds.), Leadership for learning. The new challenge in early childhood education and care (pp. 135-148). Charlotte: Information Age Publishing Inc.

Halttunen, L. (2009). Päivähoitotyö ja johtajuus hajautetussa organisaatiossa. Doctoral dissertation. Jyväskylä Studies in Education, Psychology and Social Research 375. Jyväskylä: Jyväskylä University Printing House.

Halttunen, L. (2015). Developing leadership training: Early Childhood Education leaders' views. In M. Waniganayake, J. Rodd, \& L. Gibbs (Eds.), Thinking and learning about leadership-Early childhood research from Australia, Finland and Norway (pp. 131-146). Sydney: Community Child Care Co-operative.

Hargreaves, A. (2007). Sustainable leadership and development in education: Creating the future, conserving the past. European journal of Education, 42(2), 223-233.

Hargreaves, A., \& Fink, D. (2003). The seven principles of sustainable leadership. International Centre for Educational Change Ontario Institute for Studies in Education/University of Toronto for Educational leadership.

Hargreaves, A., \& Fink, D. (2006). Sustainable leadership. San Francisco, CA: Jossey-Bass cop.

Hargreaves, A., \& Shirley, D. (2009). The fourth way. The inspiring future for educational change. California: Sage Ltd.

Heikka, J. (2014). Distributed pedagogical leadership in early childhood education. Acta Electronica Universitatis Tamperensis 1392. Retrieved August 8, 2019 from http://tampub.uta.fi/bitstream/ handle/10024/95016/978-951-44-9381-2.pdf?sequence $=1$

Heikkilä, T. (2008). Tilastollinen tutkimus. Helsinki: Edita.

Helin, E., Kola-Torvinen, P., \& Tarkka, K. (2018). Osallisuus ja osallistuminen varhaiskasvatussuunnitelman perusteissa. In J. Kangas, J. Vlasov, E. Fonsén, \& J. Heikka (Eds.), Osallisuuden pedagogiikkaa varhaiskasvatuksessa 2-Sunnittelu, toteuttaminen ja kehittäminen (pp. 11-19). Tampere: Suomen varhaiskasvatus ry.

Hujala, E. (2004). Dimension of leadership in the childcare context. Scandinavian Journal of Educational Research, 48(1), 53-71.

Hujala, E. (2019). Foreword. In P. Strehmel, J. Heikka, E. Hujala, J. Rodd, \& M. Waniganayake (Eds.), Leadership in early education in times of change. Research from five continents (pp. 9-12). Opladen-Berlin-Toronto: Verlag Barbara Budrich. 
Keski-Rauska, M.-L., Fonsén, E., Aronen, K., \& Riekkola, A. (2016). Research on a joint leadership model for early childhood education in Finland. Journal of Early Childhood Education Research, 5(2), 310-328.

Kocolowski, M. D. (2010). Shared leadership: Is it time for a change? Emerging Leadership Journeys, 3(1), 269-282.

National Core Curriculum on Early Childhood Education and Care (2018). The Finnish National Agency for Education.

Ødegård, E. (2011). Nyutdannede pedagogiske leders mestring og appropriering av barnehagens kulturelle redskaper: En kvalitativ studie av nyutdannede førskolelæreres kompetansebygging det første året i yrket. Retrieved August 20, 2019 from https://opena rchive.usn.no/usn-xmlui/bitstream/handle/11250/2438207/Nyutd annede.pdf? sequence $=1 \&$ is Allowed $=y$

Semann, A. (2019). Pedagogical leadership. Interrogating self in order to lead others. In S. Cheeseman \& R. Walker (Eds.), Pedagogies for leading practice (pp. 51-64). London: Routledge.

Sergiovanni, T. J. (1998). Leadership as pedagogy, capital development and school effectiveness. International Journal of Leadership in Education, 1(1), 37-46. https://doi.org/10.1080/13603 12980010104.

Soukainen, U. (2015). Johtajan jäljillä. Johtaminen varhaiskasvatuksen hajautetuissa organisaatioissa laadun ja pedagogisen tuen näkökulmasta. Annales Universitatis Turkuensis C 400 Turun yliopisto. Turku.
Soukainen, U. (2018). The curriculum process-Case Turku in Finland. Inquiry in education, 10(1), Article 5. Retrieved November 28, 2018 from https://digitalcommons.nl.edu/ie/vol10/iss 1/5

Soukainen, U. \& Fonsén, E. (2018). Will the leadership last? Sustainable leadership in early childhood education. In E. Rogulj, A.V. Jevtić \& A. Jurčević - Lozančić (Eds.) Early Childhood Relationships: The foundation for Sustainable Future. Proceedings. International Scientifical and Professional Conference OMEP 2017, 312-329. http://omep.hr/assets/zbornik.pdf

Ukkonen-Mikkola, T. \& Fonsén, E. (2018). Researching Finnish early childhood teachers' pedagogical work using Layder's research map. Australasian Journal of Early Childhood, 43(4), 48-56

Urban, M., \& Dalli, C. (2012). A profession speaking and thinking for itself. In L. Miller, C. Dalli, \& M. Urban (Eds.), Early childhood grows up: Towards a critical ecology of the profession (pp. 157-177). London: Springer.

Vlasov, J. (2018). Reflecting changes in early childhood education in the USA, Russia and Finland. Academic Dissertation. Acta Universitatis Tamperensis 2416. Tampere: Tampere University Press.

Publisher's Note Springer Nature remains neutral with regard to jurisdictional claims in published maps and institutional affiliations. 